Case Study

http://dx.doi.org/10.17784/mtprehabjournal.2014.12.162

\title{
Craniosacral therapy in welfare and autonomous nervous system of fighters of mixed martial arts: cases study.
}

\author{
Terapia craniossacral no bem-estar e no sistema nervoso autônomo de lutadores de artes mar- \\ ciais mistas: estudo de casos.
}

Diane Nogueira Paranhos Amorim(1), Lia Medeiros Brandim Mendonça(1), Ludmilla Karen Brandão Lima de

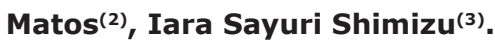

Centro Universitário Cesumar (UNICESUMAR), Maringá (PR), Brazil.

\begin{abstract}
Introduction: The Craniosacral Therapy uses tender and accurate touches to diagnose and treat the craniosacral system. The Mixed Martial Arts athletes are exposed at risk of injury during competitions, which can affect your welfare. The Craniosacral Therapy improves the functioning of the Central and Autonomic Nervous System, that promotes relaxation, sense of welfare and homeostasis in the body. Objective: to evaluate the effect of Craniosacral Therapy in welfare and Autonomic Nervous System in Mixed Martial Arts fighters. Method: We conducted a case study by analyzing the heart rate and general welfare of 05 Mixed Martial Arts fighters, eight sessions with Craniosacral Therapy, using respectively a frequency Polar RS800 and a Range of Subjective Well-Being for collection data, posteriorly it was submitted to the calculation of mean and standard deviation and "T Studant" test to compare the data before and after the treatments. Results: The initial evaluation of the athletes showed a high subjective well-being, that remained after the therapy. There was a statistically significant increase in one of the athletes with respect to positive affect (from $4.048 \pm 0.5896$ to $4.429 \pm 0.5071$ ). As for the negative affects three increased the score. There was a statistically significant reduction $(p<0.001)$ between the initial and final heart rates in each service, with averages of 68.50 and 63.28 respectively. Conclusion: The Craniosacral Therapy increases the activity of the parasympatic nervous system, promoting decreased heart rate, providing better coronary flow and that alone is not sufficient to determine an increase or decrease of well-being.
\end{abstract}

Keywords: Athletes, Heart rate, Autonomic Nervous System.

\section{Resumo}

Introdução: A Terapia Craniossacral utiliza toques suaves e precisos para diagnosticar e tratar o Sistema Crânio Sacral. Os atletas de Artes Marciais Mistas são expostos a riscos de lesões durante as competições, o que pode afetar seu bem estar geral. A Terapia Craniossacral melhora o funcionamento do Sistema Nervoso Central e Autônomo, promovendo relaxamento, sensação de bem-estar e homeostase no organismo. Objetivo: Avaliar o efeito da Terapia Craniossacral no bem-estar geral e no Sistema Nervoso Autônomo em lutadores de Artes Marciais Mistas. Método: Realizou-se um estudo de casos através da análise das frequências cardíacas e bem estar geral de 05 lutadores de Artes Marciais Mistas, em oito sessões com Terapia Craniossacral, utilizando-se respectivamente um frequencímetro Polar RS800 e uma Escala de Bem-Estar Subjetivo para coleta de dados, posteriormente submetidos ao cálculo de média e desvio padrão e teste "T Studant", para comparação entre os dados anteriores e posteriores aos tratamentos. Resultados: A avaliação inicial dos atletas revelou um alto bem estar subjetivo. Após a Terapia manteve-se o alto bem estar. Houve um aumento estatisticamente significativo em um dos atletas com relação aos afetos positivos (de $4,048 \pm 0,5896$ a 4,429 $\pm 0,5071)$. Quanto aos afetos negativos, três aumentaram a pontuação. Houve redução estatisticamente significante $(p<0,001)$ entre as frequências cardíacas inicial e final em cada atendimento, com médias de 68,50 e 63,28 respectivamente. Conclusão: A Terapia Craniossacral aumenta a atividade do sistema nervoso parassimpático, promovendo diminuição da frequência cardíaca, proporcionando melhor fluxo coronário e isoladamente não é suficiente para determinar um aumento ou diminuição do bem-estar.

Palavras chaves: Atletas, Frequência cardíaca, Sistema nervoso autônomo.

\section{Received: 7 December 2013. Accepted: 12 March 2014. Published: 30 March 2014.}

1. Postgraduate in Manual Therapy and Postural, Centro Universitário Cesumar (UNICESUMAR), Maringá (PR), Brazil.

2. Msc, Faculdade Integral Diferencial/Devry (FACID/Devry), Teresina (PI), Brazil.

3. Msc, Universidade Estadual do Piauí (UESPI), Msc, Faculdade Integral Diferencial/Devry (FACID/Devry), Universidade Estadual do Piauí (UESPI), Teresina (PI), Brazil.

\section{Corresponding Author}

Diane Nogueira Paranhos - Desembargador Fernando Sobrinho Street, n4085, Bairro Morada do Sol, Zip Code: 64053140, TeresinaPI, Brazil. Phone: (86) 3232-4569, 88043077. E-mail: diannenogueira@hotmail.com 


\section{INTRODUCTION}

CranioSacral Therapy (CST) is a therapy that uses smooth and accurate touches for diagnosing and treating the Skull Sacral System; improves the functioning of the Central Nervous System (CNS) and Autonomous (ANS) (reflecting parasympathetic and their functions, as heart rate). ${ }^{(1)}$

The Mixed Martial Arts (MMA) is so named because competitors need not follow a particular style of marcial art. (2) During competitions, athletes are exposed to serious risks of injury, which in the medium and long term can trigger headaches, depression, anxiety and irritability, affecting the general welfare of these athletes. ${ }^{(3.4)}$

This is because the general welfare is directly related to life satisfaction, positive and negative affect (which can be changed, as long-term effect of sustained blows). ${ }^{(5)}$

Because it is a technique that encourages your own natural healing mechanisms, CST causes deep relaxation and sense of well-being, promoting homeostasis in the body. ${ }^{(6)}$

The overall objective of the research was to evaluate the effect of CST on overall wellness and ANS in MMA fighters. The specific objectives were: Apply CST techniques in MMA fighters; measure the overall level of subjective well-being of MMA fighters before and after treatment and to verify the effect of CST on the parasympathetic ANS, through heart rate on fighters MMA.

\section{CASE REPORT}

\section{Characterization Study}

Experimental field research case report type, prospective with quantitative approach carried out at a gym, located on Presidente Kennedy Avenue in Teresina-PI, by analysis of heart rate and general welfare of 05 Mixed Martial Arts fighters after treatment with Craniosacral Therapy. This study was approved by the Research Ethics Committee of Cesumar (number of opinions: 303 654) and conducted according to the rules of Resolution 196/96 of the Conselho Nacional de Saúde MS research involving humans. Each volunteer signed a consent form, which was explained the objectives of the research, its methodology and freedom of the individual to accept the data exposure, with their anonymity preserved.

\section{Sample characterization}

All participants were MMA athletes, male, aged 21 to 24 years, belonging to the category of average weights for over two years, engage in combat with a frequency of every two months. For rating on weight, BMI criteria proposed by the World Health Organization (WHO) were used. ${ }^{(7)}$ The same was calculated by dividing the weight $(\mathrm{kg})$ by height squared $(\mathrm{m} 2)$. Since the adults of both genders and aged over 18 years ranked as follows: underweight (BMI $<18.5 \mathrm{~kg} / \mathrm{m} 2$ ), normal (BMI between 18.5 and $24.9 \mathrm{~kg} / \mathrm{m} 2$ ), overweight (BMI between 25 and $29.9 \mathrm{~kg} / \mathrm{m} 2$ ) and obesity (BMI $\geq 30 \mathrm{~kg} /$ $\mathrm{m} 2)$.

\section{Initial procedure}

At the first meeting all participants received an identification sheet containing initials, age, weight, height and BMI, where they met the initial fields and age. Weight, height and BMI were calculated by the researchers by weighing and measurement an anthropometric mechanical balance. After collecting the initial data, each participant completed a Subjective Well-Being Scale (EBES - Annex).

\section{Procedure Treatment}

After application of the scale (EBES) of the calls were initiated Craniosacral Therapy. In total there were eight sessions lasting 30 minutes each, twice a week, on alternate days during the month of June 2013. All calls, from 1st to 8th were made equally, without any change in behavior. Before each procedure, the subjects were instructed to not eat and only water to drink. The sessions were conducted in a quiet room with ambient temperature, where fighters were seen on a stretcher.

Heart rate (HR) data were collected from the Polar RS800 frequency meter, comprising a belt attached to the chest with the individual function of capturing the heartbeat, the pickup is located in the sternum and sends the data to a clock pulse located in the same. While one researcher applied the technique, another one was observing the HR data transmitted by the Wrist Watch Polar RS800, logging into each of the ten steps of therapy, the highest HR of the individual.

The collection of HR was performed in three phases: rest, application of CST and recovery phase. In the first phase, the participant was positioned supine on the stretcher to collect HR data at rest for $6 \mathrm{~min}$. In the second phase was applied the CST. The sessions of craniosacral therapy followed the protocol 10 steps of Upledger ${ }^{(8)}$ (release fourth ventricle, diaphragms, decompression L5-S1, dural tube, front elevation, parietal elevation, compression and decompression sphenobasilar, temporal techniques, compression and decompression temporo-mandibular joint release fourth ventricle). The HR collected was recorded in a specific table for this purpose, containing all of the items mentioned above protocol. After completion of therapy began the third stage, where the data were collected from the final HR for 6 min, with individual still supine and resting.

\section{Final Procedure}

At the end of 08 attendances CST, each of the 05 participants completed the subjective well-being scale 
again in order to compare the welfare of the same before and after treatment.

\section{Data Analysis}

Once collected, the data were organized into spreadsheet program Microsoft Office Excel 2007. They were subjected to non-parametric statistical test "T Studant" for the comparison between the earlier and later time to treatment, with significance set at $p<0.05$ and $95 \%$ CI. Subsequently graphs and tables to present the data, developed in Origins program were developed.

For the analysis of Subjective Well-Being Scale, it was considered that, for each question the participants opted for a score 1-5. For the factors of positive affect and life satisfaction, the higher the score (considering the cutoff point 3 ) better subjective well-being and negative effect, the lower the score (below average 3 ) can best be considered subjective well-being. ${ }^{(9)}$

The scores of EBES were estimated by the sum of the values assigned to each item comprising the scale mean, standard deviation was also calculated.

\section{RESULTS}

Regarding the characterization of the sample, Table 01 shows data from a homogeneous sample, with a low standard deviation. Athletes participating in the survey are young adults (under 25 years), on average are the ideal weight according to the BMI.

Regarding subjective well-being, the graph 01 shows the result of the evaluation of athletes before starting treatment and after its completion, in each area of wellness: negative and positive effects and life satisfaction. The athletes had a low score for negative affect and high score for positive affect and satisfaction with life, revealing a high well-being, according to the participants themselves.

Table 02 shows the mean score of the positive and negative affects of each participant. With regard to positive affects, there was a statistically significant increase in one of the athletes after the end of the visits of CST, in contrast, two athletes decreased their score. On the negative affects, three athletes increased score, which shows an increase in intensity of the negative feelings.

Compared to the averages of the initial and final HR in each service, the graph 02 shows a statistically significant reduction between the same (initial mean HR: 68.50; Final average: 63.28). In eight sessions of the behavior was similar frequencies, the initial heart rate was always higher compared to the end, showing that there is a reduction in HR of the individual during the application of therapy.

\section{DISCUSSION}

Anthropometric data that characterize the study sample, showed a BMI maximum indicative of overweight (mean BMI despite indicate proper weight). The adoption of BMI as a single standard classification of nutritional status can cause inaccurate reviews and an incorrect diagnosis $^{(10)}$ other studies in the literature have also demonstrated limitations of BMI. $(11,12,13)$

BMI is simply a relationship between weight and height of individuals, which has limitations as compared to the proportionality of the members and the association with fat-free mass, especially in men, because muscular development can lead to misinterpretations in the identification of obesity. This lack of congruence between BMI and body fat can be explained not only by the weakness of this index, but also by the fact that body fat is associated with levels of activity or physical fitness. ${ }^{(14)}$

Taking into consideration that the sample is composed of athletes whose sport practiced is directly related to the strength, it is quite possible that it has an excess of muscle mass and not fat.

The high score of life satisfaction and positive affects

Table 1. Anthropometric data of MMA fighters athletes studied. Teresina, 2014.

\begin{tabular}{lcccc}
\hline Variables & M & SD & Max & Min \\
\hline Height & 1.76 & \pm 0.015 & 1.78 & 1.75 \\
Weight & 74 & \pm 4.242 & 79 & 70 \\
BMI & 23.84 & \pm 1.752 & 25.79 & 22.09 \\
Age & 22.5 & \pm 1.291 & 24 & 21 \\
\hline Subtitle: M. mean; SD. standard deviation; Max. maximum; Min. minimum.
\end{tabular}

Subtitle: M. mean; SD. standard deviation; Max. maximum; Min. minimum. Source: Original data.

Table 2. Positive and negative affects of the Subjective Well-Being Scale of MMA fighters studied. Data presented as mean \pm standard deviation. Teresina. 2014.

\begin{tabular}{|c|c|c|c|c|c|c|}
\hline \multirow{2}{*}{ Fighters } & \multicolumn{2}{|c|}{ Positive affects } & \multirow{2}{*}{$\mathbf{T}$} & \multicolumn{2}{|c|}{ Negative affects } & \multirow{2}{*}{$\mathbf{t}$} \\
\hline & Start & Final & & Start & Final & \\
\hline 1 & $4.048 \pm 0.5896$ & $4.429 \pm 0.5071$ & $0.01518 * *$ & $1.038 \pm 0.1961$ & $1.192 \pm 0.4019$ & $0.0427^{*}$ \\
\hline 2 & $4.143 \pm 0.4781$ & $4.048 \pm 0.4976$ & 0.2653 & $1.808 \pm 1.0206$ & $1.615 \pm 0.8038$ & 0.2269 \\
\hline 3 & $3.714 \pm 0.9024$ & $3.523 \pm 0.7496$ & 0.2306 & $2.308 \pm 0.8376$ & $2.154 \pm 0.7317$ & 0.2419 \\
\hline 4 & $3.524 \pm 0.6016$ & $2.714 \pm 0.9024$ & $0.0007 * * *$ & $1.654 \pm 0.7452$ & $2.154 \pm 0.7845$ & $0.0112 * *$ \\
\hline 5 & $4.230 \pm 0.4364$ & $2.714 \pm 0.9024$ & $0.016433 * *$ & $1.77 \pm 0.6436$ & $2.154 \pm 0.7845$ & $0.0123 * *$ \\
\hline
\end{tabular}

Subtitle: t. "T" Studant; *significant in $\mathrm{p}<0.05 ;{ }^{* *}$ significant in $\mathrm{p}<0.01 ; * * *$ significant in $\mathrm{p}<0.001$. Source: Original data. 


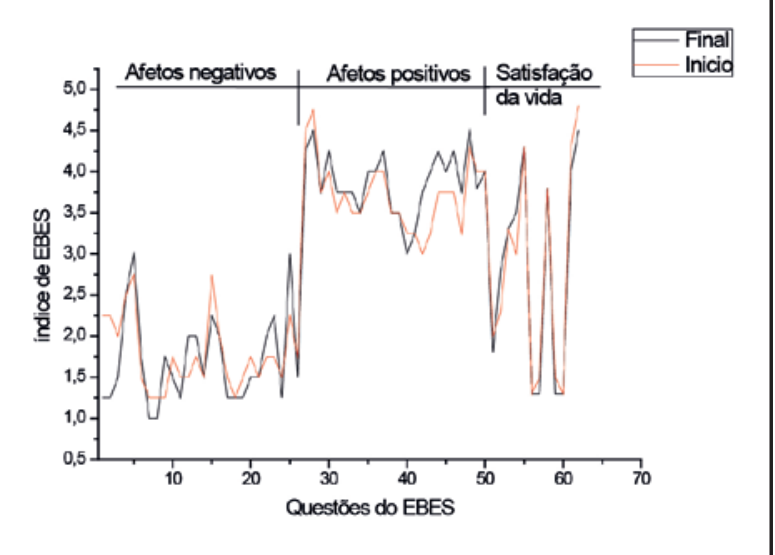

Figure 1. Subjective Well-Being Scale (EBES) in MMA fighters before and after application of the craniosacral techniques. Teresina. 2014

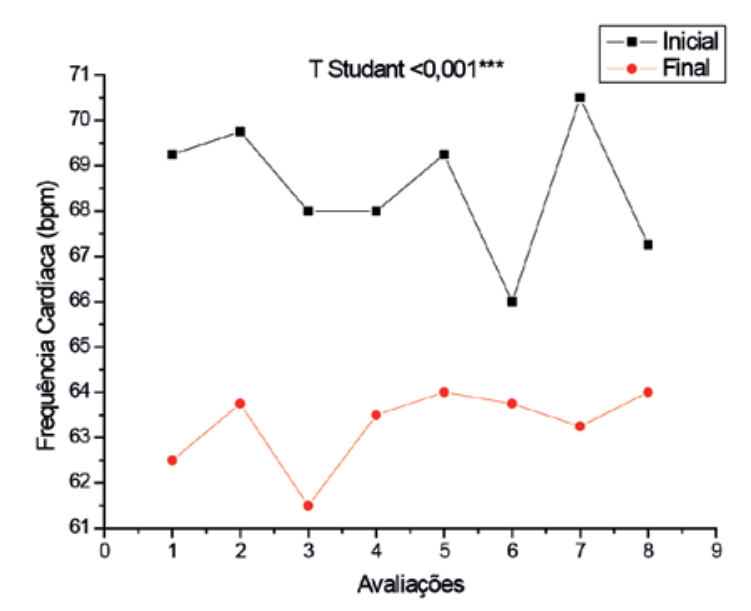

2. Heart Rate of MMA fighters before and after the application of craniosacral techniques. Teresina. 2014.

and low negative affect score (before and after TCS), showed that athletes are subjectively high welfare.

There is ample scientific evidence that regular physical activity has unquestionable benefits for physical and psychological health, which in turn are causing a significant impact on the overall well-being of the subject at all ages. ${ }^{(15)}$ In addition, gender male has higher levels of physical activity, then have higher levels of life satisfaction. ${ }^{(16)}$

There is also an influence because it is a sample of young adults, ie people who have gone through the nat- ural difficulties of the moment of transition from adolescence and now living a phase with more positive aspects of the role of adult.(17)

The fading of positive affects and increased intensity of negative affect, cited by some athletes after the sessions of CST can be explained by other factors that influenced the participants' emotional, social, physical life, or, and not by the intervention of CST.

Self-esteem can be one of these factors, is defined as the affective evaluation of the value, importance or appreciation for what one does oneself. ${ }^{(18)}$ Depending on how is this self assessment, this characteristic may be associated both with negative results as anxiety, depression and aggression, as indicators of positive functioning, thus being related significantly to the well-being. ${ }^{(19)}$

Factors such as the capacity for emotional regulation, (20) around the date of sports competitions (which can be seen as threatening situations, capable of generating varying levels of emotions such as anxiety, which positively influences negative affect, and self-generating impact positive about positive affect) may also be appointed as a direct influence on positive and negative affect and hence the welfare of athletes. ${ }^{(21)}$

The decrease of HR reveals that CST promotes a reduction in sympathetic tone, being responsible for improving the functioning of the Central Nervous System (CNS) and Autonomous (ANS) (22). The ANS exerts a positive influence on the cardiovascular system, which reflects the natural variability of cardiovascular parameters. ${ }^{(23)}$

As demonstrated by other authors ${ }^{(24,25)}$, the ANS is closely connected to the craniosacral system, so the CST can promote changes in ANS, as increased parasympathetic activity, thus decreasing the resting heart rate, providing better coronary flow and better performance to the athletes. ${ }^{(26)}$

\section{CONCLUSION}

CST promotes changes in SNA, as increased parasympathetic activity, thus decreasing the heart rate, providing better coronary flow to the athletes and increased heart rate variability. The subjective well-being is influenced by many factors, so the CST alone is not sufficient to determine an increase or decrease well-being, however, the practice of regular physical activity is a factor that positively affects subjective well-being.

\section{REFERENCES}

1. Davis CM. Fisioterapia e reabilitação: terapias complementares. Rio de Janeiro: Guanabara Koogan; 2006.

2. Scoggin JF, Brusovanik G, Pi M, Izuka B, Pang P, Tokumura S, et al. Assessment of injuries sustained in mixed martial arts competition. Am J Orthop 2010; 39(5): 247-251. 
3. Rainey CE. Determining the prevalence and assessing the severity of injuries in mixed martial arts athletes. $\mathrm{N}$ Am J Sports Phys Ther 2009; 4(4):190-198.

4. Karceski S. Concussion. Neurology 2011; 76(83):83-85.

5. Albuquerque AS. Desenvolvimento de Uma Escala de Bem-Estar Subjetivo. Psic Teor e Pesq 2004; 20(2):153164.

6. Dixon MW. Massagem Miofascial. Rio de Janeiro: Guanabara Koogan; 2007.

7. World Health Organization (WHO). Obesity: preventing and managing the global epidemic. Report of a WHO Consultation. WHO Technical Report Series 894. Geneva; 2000.

8. Upledger JE. Terapia Craniossacral. São Paulo: Roca; 2011.

9. Silva EC, Heleno MGV. Qualidade de Vida e Bem-Estar Subjetivo de Estudantes Universitários. Rev Psicol e Saúde $2012 ; 4(1): 69-76$.

10. Nunes RR, Clemente ELS, Pandini JA, Cobas RA, Dias VM, Sperandei S, et al. Confiabilidade da classificação do estado nutricional obtida através do IMC e três diferentes métodos de percentual de gordura corporal em pacientes com diabetes melito tipo 1. Arq Bras Endocrinol Metab 2009; 53(3):360-367.

11. Carrasco FN, Reyes ES, Rimler OS, Rios FC. Exactitud del índice de masa corporal en la predicción de la adiposidad medida por impedanciometría bioeléctrica. Arch Latinoam Nutr 2004; 54(3):208-86.

12. Graves MM, Adams TM. Differences in disease risk stratification based on BMI versus percent body fat values. Med Sci Sports Exerc 2004; 36(5):75.

13. Khongsdier R. BMI and morbiddity in relation to body composition: a cross-sectional study of a rural community in North-East India. Br J Nutr 2005; 93(1):101-7.

14. Glaner MF. Índice de massa corporal como indicativo da gordura corporal comparado às dobras cutâneas. Rev Bras Med Esporte 2005; 11(4):243-6.

15. Cid L, Silva C, Alves J. Atividade física e bem-estar psicológico - perfil dos participantes no programa de exercício e saúde de Rio Maior. Motricidade 2007; 3(2):47-55.

16. Lucas C, Freitas C, Oliveira C, Machado M, Monteiro M. Exercício físico e satisfação com a vida: um estudo com adolescentes. Psicol Saúde Doenças 2012; 13(1):78-86.

17. Andrade C. Transição para a idade adulta: Das condições sociais às implicações psicológicas. Anál Psicol 2010; 2(28):255-267.

18. Blascovich J, Tomaka J. Measures of self-esteem. In: Robinson JP, Shaver PR, Wrightsman LS, eds. Measures of social psychological attitudes series: Vol. 1. Measures of personality and social psychological attitudes. California: Elsevier Academic Press; 1991:115-55.

19. Baumeister RF, Campbell JD, Krueger JI, Vohs KD. Does high self-esteem cause better performance, interpersonal success, happiness, or healthier lifestyles? Psychol Sci Public Interest 2003; 4(1):1-44.

20. Freire $T$, Tavares D. Influencia da autoestima, da regulacao emocional e do genero no bem-estar subjetivo e psicológico de adolescentes. Rev Psiq Clín 2011; 38(5):184-188.

21. Fernandes MG, Vasconcelos-Raposo J, Fernandes HM. Relação entre orientações motivacionais, ansiedade e autoconfiança, e bem-estar subjetivo em atletas brasileiros. Motricidade 2012; 8(3):4-18.

22. Purdy WR, Frank JJ, Oliver B. Subocciptal dermatomyotomic stimulation and digital blood flow. J Am Osteopath Assoc 1996; 96: 285-289.

23. Fazan JR, Silva VJ. Principais fatores que interferem nas variações da pressão arterial e do intervalo cardíaco. Rev bras hipertens 2000; 7(2):180-18.

24. Upledger JE. CranioSacral therapy. Seminar in Integrative Medicine 2004; 2(4): 159-166.

25. Cutler MJ, Holland BS, Stupisk BA, Gamber RG, Smith ML. Cranial manipulation can alter sleep latency and sympathetic nerve activity in humans: a pilot study. J Altern Complement Med 2005; 11(1):103-108.

26. Regenga MM. Fisioterapia em cardiologia: da UTI à reabilitação. São Paulo: Roca; 2000. 
Subscale 1. I would like to know how you have been feeling lately. This scale consists of a few words that describe different feelings and emotions. There is no right or wrong answers. It is important that you be as honest as possible. Read each item and then copy the number expressing your answer in the space next to the word, according to the following scale.

\begin{tabular}{ccccc}
1 & 2 & 3 & 4 & 5 \\
Not a bit & a little & moderately & A lot & extremely \\
\hline
\end{tabular}

Lately I've been feeling ...

\begin{tabular}{|c|c|c|}
\hline 1) afflicted & 17) unsettled & 33) down \\
\hline 2) alarmed & 18) animate & 34) frightened \\
\hline 3) kind & 19) determined & 35) disgusted \\
\hline 4) active & 20) upset & 36) aggressive \\
\hline 5) distressed & 21) decided & 37) stimulated \\
\hline 6) pleasurable & 22) secure & 38) troubled \\
\hline 7) happy & 23) scared & 39) well \\
\hline 8) apprehensive & 24) dynamic & 40 ) nervous \\
\hline 9) worried & 25) engaged & 41) excited \\
\hline 10) willing & 26) productive & 42) vigorous \\
\hline 11) glad & 27) impatient & 43) inspired \\
\hline 12) angry & 28) apprehensive & 44) tense \\
\hline 13) depressed & 29) enthusiastic & 45) sad \\
\hline 14) interested & 30) discouraged & 46) agitated \\
\hline 15) bored & 31) anxious & 47) ashamed \\
\hline 16) attentive & 32) undecided_ & \\
\hline
\end{tabular}

Subscale 2. Now you will find some phrases that can identify opinions you have about your own life. Please, for each statement, mark with an $\mathrm{X}$ the number expressing your opinion as accurately as possible about your current life. There is no right or wrong answer, what matters is your sincerity.

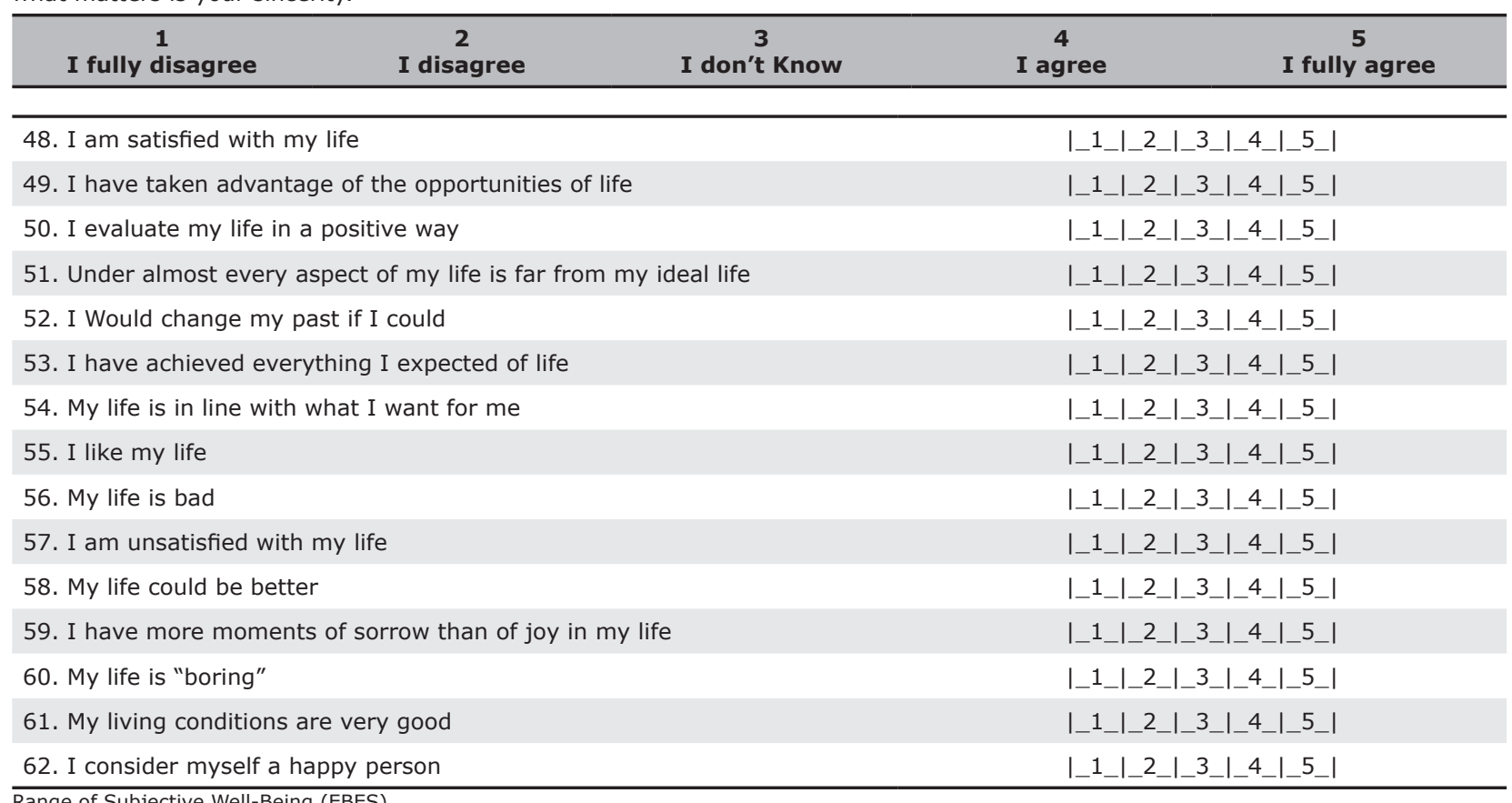
Range of Subjective Well-Being (EBES). 